\title{
BETWEEN THE COLONIAL HERITAGE AND THE FIRST GLOBALIZATION BOOM: ON INCOME INEQUALITY IN THE SOUTHERN CONE*
}

LUIS BÉRTOLA

Universidad de la República, Uruguay ${ }^{\text {a }}$

CECILIA CASTELNOVO Universidad de la República, Uruguay ${ }^{\text {b }}$

JAVIER RODRÍGUEZ Universidad de la República, Uruguay ${ }^{\mathrm{c}}$

HENRY WILLEBALD

Universidad Carlos III de Madrid, Spain ${ }^{\mathrm{d}}$

\begin{abstract}
This paper presents a first estimate of income inequality in the Southern Cone of South America (Brazil 1872 and 1920, Chile 1870 and 1920, Uruguay

* Received 21 December 2009. Accepted 22 March 2010. This paper was written as part of the project «A Global History of Inequality in the Long $20^{\text {th }}$ Century», directed by Luis Bértola and financed by CSIC, Universidad de la República, Uruguay. We thank Peter Foldvari, Pablo Gerchunoff, Herbert Klein, Peter Lindert, Branko Milanovic, Leonardo Monasterio, Leandro Prados, Eustaquio Reis, Jim Robinson, Jan Luiten van Zanden, Andrea Vigorito and Jeffrey Williamson for their comments and advice, as well as participants at workshops and congress sessions on income inequality at Universidad de Valencia, 1er Congreso Latinoamericano de Historia Económica (Montevideo 2007), XIV International Economic History Congress (Helsinki 2006), «Inequality Beyond Globalization» Conference (Neuchâtel, June 2008), Universidad de Barcelona, Universidad Complutense de Madrid, and participants at the Conference: "A Comparative Approach to Inequality and Development: Latin America and Europe» (Madrid, May 2009). The usual disclaimers apply. We also thank Tania Biramontes for excellent research assistance. Luis Bértola acknowledges support by European Science Foundation Globaleuronet, Universidad Carlos III, Madrid, and Harvard University, where he was hosted as Visiting Professor and partly developed this project. Henry Willebald would like to thank Instituto Figuerola, Universidad Carlos III, for supporting his research activity as a PhD candidate. Finally, we thank two anonymous referees who provided important insights that helped to improve this final version.

a lbertola@fcs.edu.uy

b ccastelnovo@fcs.edu.uy

c jerweber@fcs.edu.uy

d $\overline{\text { hwilleba@clio.uc3m.es }}$
\end{abstract}


$1920)$ and some assumptions with regard to Argentina (1870 and 1920) and Uruguay (1870). We find that income distribution was relatively high on the eve of the first globalization boom. Thus, inequality is not only the result of globalization, but also a structural feature. Inequality increased between 1870 and 1920 , both within individual countries and between countries. Globalization forces do not result in obvious outcomes. Rather, the effect of globalization on inequality depends on the expansion of the frontier and institutional persistence and change in old and new areas. Inequality was clearly high in the wake of the globalization process. This was a particular kind of inequality, which was part of a set of institutions closely linked to the exports of primary goods, sluggish technological change and limited human capital formation.

Keywords: Latin America's Southern Cone, inequality, first globalization boom, institutions, economic growth

JEL Code: N16, N36

\section{RESUMEN}

Este artículo presenta una primera estimación de la distribución del ingreso en el Cono Sur de Sudamérica (Brasil 1872 y 1920, Chile 1870 y 1920, Uruguay 1920) y algunos supuestos sobre la desigualdad en Argentina 1870 y 1920, así como en Uruguay en 1870. Encontramos que la distribución del ingreso era relativamente alta en los albores de la primera globalización, por lo que la desigualdad del ingreso no solamente debe ser vista como el resultado de la globalización, sino como una característica estructural. La desigualdad aumentó entre 1870 y 1920 , tanto dentro de cada país como entre los países del Cono Sur. Las fuerzas de la globalización no generan resultados obvios. Por el contrario, el impacto de la globalización sobre la desigualdad depende de la expansión de la frontera y de la persistencia y el cambio institucional en las viejas áreas y en las nuevas. La desigualdad fue particularmente alta al culminar la globalización. Se trató de una forma particular de desigualdad, que formó parte de un conjunto de instituciones estrechamente vinculadas a una economía exportadora de bienes primarios, con escaso desarrollo tecnológico y bajos niveles de formación de capital humano.

Palabras clave: Cono Sur de América Latina, desigualdad, primera globalización, instituciones, crecimiento económico

\section{INTRODUCTION}

Latin America is the continent with the highest inequality levels and economic growth has not changed this long-term trend. In fact, income inequality has worsened in recent decades. 
There has been heated debate on the origins of Latin American inequality. While some scholars have stressed its colonial roots, others have emphasized the role played by the first globalization boom. Still others focus on the import-substituting-industrialization (ISI) period.

Latin America is also a region that has been growing at a pace equal to the world average at a time when growth rates worldwide have been diverging. While the region has not been stagnant, no Latin American country has grown rapidly and well enough to be labelled as a developed country. An obvious question, then, is whether high inequality levels have hindered Latin American growth or whether the lack of fast growth is the cause of the relatively high inequality levels in a Kuznets-like approach.

This paper focuses on the question of whether inequality is a structural feature of Latin American economies, as represented by the Southern Cone (LASC) countries (Argentina, Brazil, Chile and Uruguay), or whether inequality has only been a particular characteristic of Latin America since the first globalization boom.

In order to address this issue we provide new estimates of income inequality in the Latin American Southern Cone before the strong impact of globalization was perceived and at the zenith of the first globalization boom, ca. $1870-1920$.

The quality of the data does not allow us to be precise with regard to the absolute levels of inequality or to compare them with contemporary figures. However, what we learn from this study is that inequality was already high before the process of globalization and inequality seems to have increased both within and between LASC countries during the first globalization boom. The relative gap between the LASC countries and the core countries, on the contrary, decreased.

Furthermore, the paper concludes that the particular patterns of colonial development in each country influenced the way in which the impact of globalization manifested itself. There were differences in countries dominated by slave labor, like Brazil, in regions similar to those of the core of the colonial hacienda, like the central valley of Chile, and in regions where the expansion of the frontier was the dominant feature, as in the Río de la Plata and Northern Chile.

The next section outlines the current debate and advances our point of view with regard to institutions and globalization. Section 3 presents our estimates and discusses some empirical results. Section 4 discusses the results in terms of institutional heritage and globalization. Section 5 offers some conclusions.

\section{HISTORY AND THEORY}

\subsection{The state of the art}

According to a wide range of studies carried out between the 1950s and the 1970s, the roots of Latin American underdevelopment are to be found in 
the colonial period, when both a domestic structure of wealth concentration and international dependency relations were responsible for a pattern of development characterized by sluggish growth and high levels of social and economic inequality (Frank 1967; Stein and Stein 1970; Furtado 1974; Cardoso and Faletto 1967, 1979; Cardoso and Pérez Brignoli 1979; and many others). These authors generally had a negative view of what we now call the first globalization boom, as it combined an authoritarian construction of national states, the reinforcement of power and wealth concentration in the hands of an oligarchy, which, in turn, was highly dependent on markets, trading, finance, services and technology in the hands of foreign companies and states.

During the last decades of the $20^{\text {th }}$ century, however, the intellectual atmosphere shifted toward different approaches that have taken for granted that Latin American backwardness was mainly a $20^{\text {th }}$ century problem. The core idea was that inward-looking growth, state interventionism, forced and artificial industrialization and different varieties of populism were the main causes of the disappointing economic and social outcomes of Latin America until the 1980s. By following global best practices, Latin America should have caught up with the developed countries, as the South-East Asian countries had recently done. Accordingly, what we now call the first globalization boom appeared as the golden path to development and deviation from this path cost Latin America dearly.

In the past decade, studies of the relationship between inequality and economic growth experienced a significant revival. Jeffrey Williamson's $(1995,1999,2002)$ main message was that Latin America did relatively well during the first globalization boom and could have done much better had it been less protectionist. Latin America also suffered an increase in inequality due to the outcome of factor price convergence: the price of land increased significantly in relation to wages, while immigration intensified. The terms of trade moved in favor of Latin America, strengthening the position of landowning classes and inhibiting structural change in the long run.

Neo-institutional economic history (Engerman and Sokoloff 1997, 2000; Landes 1998; North et al. 2000; Acemoglu et al. 2002, 2005; Robinson 2006), has agreed with the previous thesis regarding the colonial roots of Latin American inequality and backwardness. Even though they give different explanations of the origins and causes of the institutional settings in Latin America, they all stress that the institutional setting, which emerged soon after the conquest, is the main explanation for long-run trends. The major features of these institutions were wealth concentration, mercantilism, religious and cultural intolerance, racism and exclusion, authoritarian and centralized states, low human capital formation, limited political democracy and the extensive presence of many kinds of privileges for the elite. Implicit in this line of research is the idea that what happened in Latin America over the past two centuries followed the path of this previous period. 
This resembles Braudel's ideas of the longue durée. However, long-run jails are no longer cultures, but institutions.

The strong emphasis that neo-institutionalists put on the colonial heritage has given rise to several reactions.

Coatsworth (2008) says that the local Latin American elite were too weak to be very rich. This helps explain why the colonial regime lasted longer than in the North. According to him, what Latin America needed was a stronger elite and more inequality in order to grow. This increasing inequality took place during the globalization period and was good for growth. "The conditions that Engerman-Sokoloff and Acemoglu, Johnson, and Robinson saw as blocking economic growth were in fact the conditions that made it possible», but some hundred years later. Growth, in turn, was more intensive in those regions where institutional reforms advanced more quickly and where the local elite faced fewer challenges from international competition and from below.

Williamson's paper in the present volume, based on Milanovic et al. (2007), says that inequality cannot be very great if per capita GDP is low, because there will not be a large enough surplus for the elite to appropriate. Inequality in Latin America during the colonial times could not be too high and was not high in contrast with Europe. Thus, this is not a possible explanation for Latin America's long-run divergence. Latin America's relatively high inequality is mainly a late $19^{\text {th }}$ century phenomenon, and can be explained using the traditional Heckscher-Ohlin $(\mathrm{H}-\mathrm{O})$ approach, as a pure economic mechanism in relation to globalization forces, driven mainly by the transport revolution.

\subsection{Our approach}

\subsubsection{Colonial heritage}

While the idea of colonial heritage seems to be a plausible one, it does not necessarily mean that what happened in subsequent periods was almost a foregone conclusion. Similarly, the changes that took place during the first globalization are not necessarily disconnected from the colonial roots. However, this period was full of new events and new international and technological conditions that interacted with and shaped institutional development.

Previous contributions to Latin American economic history agree on the profound changes that occurred during the first globalization and on the variety of transitions in Latin America to what Cardoso and Pérez Brignoli (1979) called peripheral capitalism (Cardoso and Faletto 1967; Duncan and Rutledge 1977; Sunkel and Paz 1982; Bauer 1986; Glade 1986; BulmerThomas 1994; Bértola and Williamson 2006). There is general agreement on the existence, in very broad terms, of three kinds of transitions: the tropical regions where plantation economies operating on the basis of slave labor 
were dominant; the centers of the colonial conquest, that is, the highlands of the Andean region and Meso America, and the frontier regions, especially those with temperate climates (Cardoso and Pérez Brignoli 1979; Engerman and Sokoloff 1997; Bértola and Williamson 2006).

Following Cardoso and Pérez Brignoli (1979) and Bértola (2010), the period from the second half of the $18^{\text {th }}$ century to the first globalization can be understood as a transition in which Latin America re-arranged its links with a completely new international context: the British colonies had emancipated themselves, an industrial revolution had taken place and had been diffused to other western European countries, new political and economic power relations prevailed in Europe after the Napoleonic Wars and a second industrial revolution was taking shape, of which the transport revolution was just one expression.

This transition combined three different processes: liberal reforms, the abolition of slavery and the appropriation of new frontier land. A different combination of these three processes took place in every Latin American country and interacted with the prevailing economic and social structures. The resulting institutions grew out of the complex interaction trends and forces, both domestic and international. One shortcoming of the new institutional approaches is that the equilibrium of forces created at the beginning of the conquest seems to remain rather unchanged, and that the analysis remains strongly focused on the domestic level, underestimating the strong, mainly informal, links that Latin America continued to have with the leading countries, markets, investors and governments. These aspects are more clearly seen when considering that the patterns of economic growth in the leading economies changed radically after the industrial revolution and that this had a great impact on international trade, specialization and technological change and transfers. The relationship between growth and institutions did change, both at the domestic and the international levels (Bértola 2010).

\subsubsection{Was Latin America not particularly unequal before the first globalization and was increasing inequality good?}

The idea that Latin America was not particularly unequal at the end of the colonial time is striking ${ }^{1}$. Williamson's estimated inequality for Latin America presented in his paper (Figure 3, in this volume) seems to show that the inequality levels of the late colonial period were first surpassed at the beginning of the $20^{\text {th }}$ century. This means that during most of the globalization period inequality was lower than in late colonial times, so inequality could not be the result of globalization, but rather, is a more structural feature. Globalization forces could explain fluctuations, but not average levels.

\footnotetext{
1 This section draws heavily on Bértola et al. (2009).
} 
Nevertheless, inequality is a complex concept. According to a sample of Latin American countries amounting to 14 million people at the end of the colonial period, 16 per cent were black (i.e. slaves), only 21 per cent were white, while the rest were Indians, Mulattos, Mestizos and others (Newson 2006, Table 5.3, p. 160). Most of the non-white population had several restrictions on their political and economic rights. We also know that the colonial economy did not evolve toward a free labor system, but to a very complex set of labor relations combining different forms of payments of wages with a wide variety of coercive labor relations (Monteiro 2006). Most of the Latin American population lived and worked under these circumstances.

The idea that inequality can favor growth, as Coatsworth (2008) puts it, is not new and looks like an argument against the universal neo-institutionalist's implicit growth model. In spite of the profound changes linked to the first globalization boom in Latin America, which led to higher growth rates, what matters is the kind of growth that took place and the consequences of these patterns for continued growth. Modern economic growth implies that knowledge is systematically used to transform nature and society. Latin American growth was based on the exploitation of natural resources. Technical change was often quite limited. Contrary to what pro-global theorists have believed, the first globalization boom was not strong enough to produce a break with the informal and formal institutions that had evolved over the years and were so deeply rooted in Latin American society. Quite the contrary, in fact, as the structuralist tradition and Cardoso and Pérez Brignoli have correctly stressed, the first globalization boom often ended up interacting with or even strengthening the power of landed, commercial and political elites. In doing so, the kind of development and the kind of inequality produced were different from the inequality that tended to empower a technologically dynamic industrial sector in other regions.

The Latin American settler economies, such as those of Argentina and Uruguay, were the most successful in the region. They shared some characteristics that influenced this outcome: the production of goods competing with European producers on the basis of free labor and with a good location close to the coast and the relative weakness of colonial institutions due partly to low population density. It is possible to argue that due to the particular scarcity of labor and easy access to standard technology by a large share of the immigrant population, settler regions showed lower inequality levels than slave societies or the Andean regions. However, even in these cases the pattern of land appropriation differed significantly from other settler societies such as Australia and New Zealand. The way in which land was appropriated is the combination of new forces and patterns of behavior and institutional features that clearly show the colonial heritage, more in the informal relations than in the formal ones. The result caused large differences in the innovative capacities of the two groups of 
economies and in the way the factorial distribution of income took place between landowners, capitalists and workers, favoring land rents in the Rio de la Plata (Álvarez 2007). In a large country like Argentina considerable regional differences can be found. The province of Buenos Aires showed relatively low levels of land concentration at the end of the colonial period and during the early independence period (Gelman and Santilli 2010), but this was not the case in the northern provinces where the colonial heritage was stronger.

\subsubsection{Globalization and the expansion of the frontier}

Current research on $19^{\text {th }}$ century globalization has been focused on the application of the neoclassical theory of international trade. Applying the Stolper-Samuelson theorem based on the $\mathrm{H}-\mathrm{O}$ model, results in an approach that presents price convergence as the central pivot of the definition, identification and measurement of globalization (Harley 2007).

However, instead of approaching globalization as a regime switch to openness (O'Rourke and Williamson 2005, p. 21) with expected factor and commodity price convergence, $19^{\text {th }}$ century globalization can be seen as the expansion of the North-Western European frontier to new regions that had not been integrated into the capitalist world economy. Globalization may be «defined as a shift from an economy where local supply and demand fluctuations dominated price fluctuations to one in which the economy became a price-taker to global forces» and, if this is the case, «it need not depend on price convergence» (Harley 2007, pp. 240-241). In other words, if global markets are characterized by uneven technological change, due to the varying social and geographical contexts in which technical change is embedded, if labor markets are made up of complex institutions promoting varied versions of coercive work, if international markets are mediated by complex and often oligopolistic commercial and financial structures, and if the frontier is being extended to new regions where new institutional settings develop, then globalization will hardly adopt the form of price convergence and the historical process in question is significantly simplified by looking at it only from this point of view. The distributional outcomes are thus far from obvious.

Another concern with the $\mathrm{H}-\mathrm{O}$ approach is the strong assumptions underlying it. The two most mentioned are the supposition of constant returns to scale and that technology is ubiquitously available. What are the implications of both assumptions in this case? If we assume that the same technology is available everywhere, we also assume that once markets move toward equilibrium growth rates, factor prices will tend to converge. Furthermore, if technology is freely available, then there will be no changes in productivity growth and per capita income may arise. As a consequence, factor allocation becomes the key explanation of economic performance. 
Productivity growth and its determinants almost disappear from the scene and from the core of the analysis. It does not consider that scale economies are especially important in transport networks and in frontier expansion. Different social institutional and organizational patterns have a long-lasting impact on productivity growth and technical change. Moreover, they have an impact on the way in which the fruits of technological change are distributed, both within and between countries and regions.

Therefore, with regard to the traditional $\mathrm{H}-\mathrm{O}$ approach, one obvious complement is that these forces may produce different impacts on inequality according to the specific settings of actors and institutions. The impact of these trends may be quite different in family-based farmer economies with access to well-developed free labor markets, than in, say, a slave economy like Brazil during most of the $19^{\text {th }}$ century, or hacienda-dominated Chile in the $19^{\text {th }}$ century. Trends in land-labor ratios do not say too much about absolute inequality levels and social features of different societies.

In addition, we can examine whether or not we can treat globalization forces as a one-off change in factor endowments and a subsequent adjustment to this new equilibrium. The best way to approach this trajectory is as a process in which technological change and economic growth produce waves of productivity growth, in turn altering transport and commodity prices. Two different outcomes may be noticed. First, globalization makes new productive factors available and the increased supply causes the relative factor price to fall. This makes these new regions competitive in distant markets. Later, the expansion of demand for these new factors may raise their relative prices. However, this is not a one-off change, but rather a process of continuously counteracting forces. Therefore, the expected outcome has to do with what the frontier looks like: how fast productivity grows in maritime transport, channel and railroad building, engineering infrastructure, etc. Obviously, the cost of introducing new amounts of factors of production (land) also depends on institutional contexts: the strength of the state and the elites, the interaction between colonizers and native populations, property rights, access to labor, control of commercial networks, etc.

This point about the decisive role of institutions has been a classical one. It is sufficient to mention Adelman's comparison between Argentina and Canada and the recent contributions on New Zealand and Uruguay (Álvarez 2007). More recently, García-Jimeno and Robinson (2009) made a similar point. They proposed that in the case of Americas, most countries had an open frontier in the mid- $19^{\text {th }}$ century, and the manner in which frontier land was allocated differed significantly. They suggested that if political institutions were bad at the time of the settlement, the existence of such a frontier could lead to worse economic performance. It would be associated with the fact that it would provide a resource that non-democratic political elites could use to strengthen themselves in power. 


\section{ESTIMATING INEQUALITY IN THE SOUTHERN CONE}

\subsection{Antecedents}

Many efforts have been made in recent decades to increase the availability of information and the situation has improved recently. However, serious problems persist and any attempt to discuss any topic in economic history has to start by making a major effort to obtain data. This paper is no exception.

Williamson has repeatedly used rent-wage ratios to compare trends in different groups of countries (land- and labor-abundant; center and periphery, etc.) with very interesting results. For the cases of Argentina and Uruguay, the trend during the first globalization boom is very clear: the rent-wage ratio increases significantly up to World War I (Williamson 2002). This pattern is also common to other settler economies, such as Australia and New Zealand (see Figure 1). One of the shortcomings of these series is that they show significant changes and variations in terms of real income distribution, which are difficult to believe. What is more, they probably show the relationship between extreme components of the distribution, ignoring changes in the middle. In addition, wage data series are based on unskilled workers' wages, therefore excluding improvements in skill premiums. Another shortcoming of Williamson's proxies is that they do not show absolute levels and are difficult to

FIGURE 1

NEW SETTLEMENT ECONOMIES: WAGE-RENT RATIOS, 1870-1944 $1911=100$

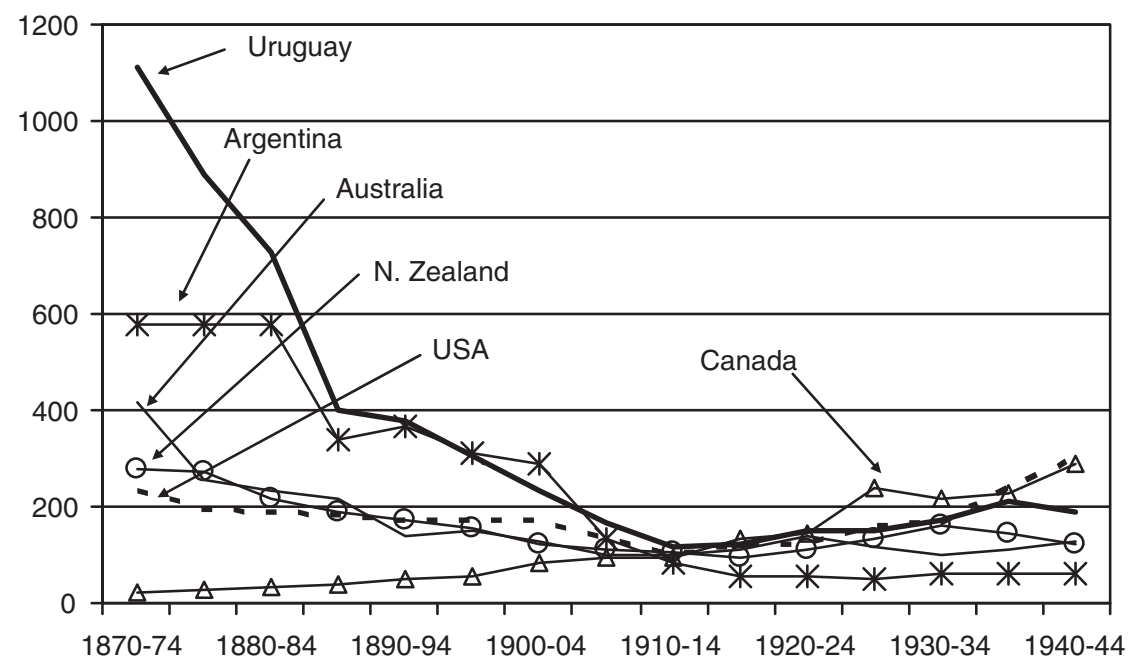

Source: Williamson $(2000,2002)$ and Willebald (2007). 
aggregate. Besides, some results appear to be contradictory: the rent-wage ratios in Argentina are increasing at the same time as the land-labor index moved from 29 to 100 between 1883 and 1911 (Williamson 2002, Table A3).

Williamson, and later Prados de la Escosura (2005 and 2007), constructed a GDP per worker series to compare with the real-wage index. This series is expected to be less volatile. Besides, Prados de la Escosura reports 9-year moving averages. His results also indicate a trend of increasing inequality during the first globalization boom. This latter attempt, although it is also valuable, may suffer from limitations similar to that of Williamson. One of them is to compare real wage data deflated by consumer price indices with the estimates of GDP figures deflated by GDP deflators or simply estimated through volume estimates. In spite of such criticisms, these estimates have been very useful.

This paper is strongly inspired by concerns similar to those that inspired Bourguignon and Morrisson (2002). Until some years ago, income distribution was discussed in two different and relatively independent ways. One strand of research was centered on the convergence-divergence debate, that is, the inequality trends in average per capita incomes between countries. Income distribution within countries was thus neglected. A second strand of research dealt with cross-section studies of country data pairs for per capita income and distribution (Gini coefficients). The aim of these studies was to establish correlations between per capita income levels and inequality levels, most of them trying to find the Kuznets curve (Kuznets, 1955). Such studies were concerned with within-country inequality and did not take international inequality into account.

Bourguignon and Morrisson (2002) attempted to overcome the restrictions of both approaches through the construction of a world database for 1820-2000 on the basis of national population, GDP and inequality estimates. Using purchasing power parity (PPP) GDP measures (Maddison 2001) and national inequality measures, the Gini coefficients were transformed into deciles assuming a lognormal distribution. The average income of the different deciles could later be added to a single database.

Bourguignon and Morrisson's (2002) courageous attempt faced several problems, the most important being the lack of historical data for many countries and regions. In order to bridge this gap, they made some important assumptions. In the case of Latin America, the assumption made was that inequality had not changed between 1820 and 1950 because of the fact that Latin American inequality had been structurally high. This assumption made it possible to take into account changes in between-country inequality, as different countries' per capita GDP and population grew at different rates. An assumed Gini coefficient «simply» helps to measure the impact of other known components.

However, what was a reasonable assumption cannot be a comfortable endpoint, especially when much evidence suggests that inequality really did 
change and fluctuate. Nevertheless, to Bourguignon and Morrisson's (2002) credit, our results point to the fact that inequality seems to have been structurally high in Latin America.

\subsection{Present estimates}

In what follows, we will present our attempt to make progress in estimating income inequality in the LASC ca. 1870 and 1920. The reason for selecting this sample is quite simple: these are the countries we understand best and for which we have better information. The objective is to include more countries in the future, especially Mexico and Colombia. LASC is also a defendable unit of analysis from a different point of view. All the main geographical categories that exist in Latin America as a whole are represented in this region; it includes the temperate areas, which can be considered an extension of the European frontier; it includes tropical regions, as in the case of Brazil, and it also includes highlands as in the case of Chile and Northeast Argentina. The three cases are also examples of the three aforementioned transitions. The Río de la Plata, Northern and Southern Chile are examples of frontier expansion and Brazil is a good example of a slave society. Although the central valley of Chile is not a classic example of the Andean transition, it does resemble these cases due to the important role played there by the hacienda system.

The benchmark years have been selected for historical, theoretical and empirical reasons. The empirical reasons have to do with the data for Brazil. The population censuses of 1872 and 1920 conditioned the final selection of benchmark years to a large extent. From a historical and theoretical point of view, 1872 represents a point in time when globalization was still not very pervasive, while 1920 represents a moment when globalization was at its zenith. None of the selected years are uncontroversial.

By the 1870s globalization forces had been active for a long time. In Chile, for example, the wheat cycle described in Rodríguez Weber (2009) was the result of a demand shock from Australia and California that had the effect of worsening the income distribution in the central valley. It ended with the crisis of the early 1870s and wheat production never recovered, precisely because globalization meant that Chilean wheat production was not competitive compared with that of Argentina, North America and other countries. There is general agreement that globalization forces began to affect Latin America from the 1870s onward due to a complex set of interacting forces; a noticeable expansion of the frontier, the development of railroads and other infrastructure (harbors, roads, telegraph and channels), and most importantly, the consolidation of national states. This consolidation responded to both the institutional improvements and the empowerment of the central state and its armed forces, enhancing its ability to enforce 
the rights of property owners and to "pacify» the frontier. In short, even if globalization forces at the international level had already been active for some time, in Latin America their impact was more noticeable from the 1870 s onwards.

Regarding the 1920 benchmark year, a possible objection to this date is that after the World War I the backlash against globalization was already underway. However, there is discussion as to whether the export-led era continued until the crisis of 1929 or whether the trend had already changed before the World War I (Thorp 1986). With respect to the countries in this study, the two cases for which we have information (Chile and Uruguay) show that the inequality levels in 1913 and 1920 are very similar: 0.580 and 0.577, respectively, in Chile (Rodríguez Weber 2009, Cuadro AE.2); 0.580 and 0.578 in Uruguay (Bértola 2005, Cuadro A.1).

\subsubsection{Brazil}

A detailed presentation of the estimate for Brazil may be found in Bértola et al. (2009). The estimate uses Brazilian population census figures from 1872 and 1920. Both censuses contain information on gender and condition (free or slave) at the province (19 in 1872) and state (21 in 1920) levels, for fortyeight different professions.

The strategy was to assign income to this population using a wide range of sources and assumptions.

\section{2}

In 1872, about 1.5 million people, out of an estimated active population of more than 6 million, were slaves. In our study, they were assigned income according to different reports on the cost of the maintenance of slaves. In cases in which the activity required a special skill, income was adjusted in proportion to the increase in the price of slaves with this skill. The difference was on average about 25 per cent.

Obviously, there were differences among different slaves' income due to gender, access to land, production for own consumption, the duration of a working day, etc. It seems realistic, however, to assume that the differences among the slaves did not significantly increase total inequality in Brazilian society in 1872 .

About 5 per cent of the active population consisted of civil servants. Our database includes official information regarding the income of each and every one of them.

With respect to women, the income assigned was two-thirds the income assigned to men. This was the average result obtained from many different sources of information. In the cases of capitalists and owners and in the case of slaves, the same income as that of men was assigned. 
Our third important group of data is the list of voters at the municipal level. The Brazilian electoral system was institutionalized in 1821 and was well developed by the 1870s. This kind of information is very limited. We have access to complete lists for the state of Río Grande do Sul (RGS, more than 2,000 cases) and processed information for São Paulo (SP; Klein 1995) and Río de Janeiro (RJ; Nunes 2003). Fortunately, the income limit necessary in order to obtain the right to vote was extremely low: 200 mil-réis (slaves' «income» was estimated to be 64 mil-réis). The register for RGS, kindly provided by Leonardo Monasterio, includes more than 2,000 observations indicating the voter's profession, compatible with the census arrangement of professions and income.

Applying information on income distribution for professional categories of the province of RGS to the rest of the states, and taking into account mean income levels of the active population, we estimate income for all the categories. The detailed estimation can be found in Bértola et al. (2009).

The database assigns income to about 5.6 million people out of an active population slightly above 6 million.

\section{0}

This estimate is also based on the population census. It assigns income to 8.1 million people out of an active population of 18 million. The main sources for income are as follows.

1. A list of 32,000 civil servants (out of 186,000) with detailed information on income and profession.

2. A survey of wages in the secondary sector with the number of workers by twenty-one income intervals (eight male adults; five female adults; four male workers, 14-20 years; and four female workers, 14-20 years), for fourteen branches and twenty-one states. The survey covers about onefifth of the total population registered by the census in these activities.

3. Information on average wages for ten categories of primary workers at state level (21 administrative jurisdictions).

4. An estimate of landowners' income, according to census data on the size of farms and wage ratios for 1920 and regional productivity differences for 1940.

5. An estimate of industrial capitalists' incomes, using the industrial survey from 1920, and assuming the existence of one owner per enterprise.

If the database is expanded to the whole active population according to the census and using the obtained average income, a total income of 17.3 billion mil-reis is obtained, compared to 14.9 billion estimated by Goldsmith (1986, p. 147, Table IV-2). 


\subsubsection{Chile}

Detailed information on how the Chilean estimates were constructed can be found in Rodríguez Weber (2009) and Bertola and Rodríguez Weber (2009). First we organize the population according to the economic activity in which they are engaged. Then we search for information in order to assign each occupational group an income. Thus, our database contains information on the active population with an identifiable profession. The changing structure of the active population by sector of activity (agriculture, mining, manufacturing, construction, transport and communications, commerce and others) is based on Gálvez and Bravo (1992), but many corrections were introduced in order to make the available information compatible. These large sectors include several occupations each. Additional disaggregation was made for some professions, such as the agrarian sector and mining. On the contrary, other professions were grouped in fewer units.

With respect to income, several different sources were used and made comparable for both years. When prices or income were not directly available, factor price series were applied to existing data in order to complete the information for both years. In some cases, the values are the result of interpolation between other available years.

\subsubsection{Uruguay}

We begin with the 1920 estimate, as the 1870 estimate relies on the former.

\section{0}

The 1920 inequality estimate is provided by Bértola (2005) and takes into consideration an exhaustive series of civil servant incomes, eight income categories for industrial workers in eight different industrial branches and the whole agrarian sector, including owners and tenants, according to the size of farms and wage earners. The database covers about 70 per cent of the active population.

1870

We do not have our own inequality estimate for 1870, as we do for 1920 . In section 4, we will discuss the so-called Inequality Possibility Frontier (IPF) as proposed by Milanovic et al. (2007). According to the value obtained for Uruguay in 1920 and assuming a subsistence income of $\$ 400$ (based on the 1990 value of international dollars; implying that inequality should be almost zero at that average income level), we estimated a polynomial regression (third order) to obtain a hypothetical value for 1872. This value helps us assign weight to other Uruguayan variables such as per capita GDP and population. Alternatively, we will also estimate Southern Cone inequality as if income inequality in Uruguay did not change between 1870 and 1920. 
As we will see, the impact on the aggregate inequality of the Southern Cone from using this alternative assumption is very small.

\subsubsection{Argentina}

Unfortunately, it has not yet been possible to make much progress in the estimation of Argentine income distribution. In order not to exclude the important role played by Argentina in the region with respect to per capita GDP and population growth, we have decided to make some assumptions regarding its inequality levels. As in the case of Uruguay, we will start in inverse chronological order.

\section{0}

In order to estimate total inequality in Argentina, we assumed that the Gini coefficient within each Argentine province was similar to that of Uruguay in 1920. Since we have estimates of the per capita GDP of the different provinces (Llach 2004), total Argentine inequality was increased with respect to each province's inequality, as we added a between-province inequality component. Thus, while the estimated Uruguayan Gini coefficient in 1920 is 0.562, the estimated Argentine coefficient is 0.574 .

\section{0}

For 1870 a similar procedure to that used in the case of Uruguay was followed. As we do not have reliable information on how differences in per capita GDP at the province level evolved, relative per capita GDP levels of the different provinces were assumed to remain constant, that is, all provinces' per capita GDP was assumed to grow at similar rates. However, we allowed for changes in every province's population. We will use two alternative measures, as in the case of Uruguay, when computing total Southern Cone inequality. The first estimate uses the IPF approach and the second assumes that inequality at the province level did not change.

In short, these very large assumptions about Argentine domestic inequality allow us to take into account the impact of Argentine population growth and Argentine per capita GDP growth on total inequality in the Southern Cone.

\subsubsection{Southern Cone}

The estimate of total inequality in the Southern Cone was obtained in the following way:

1. The estimate or assigned country Gini coefficients are transformed into deciles assuming a normal distribution. 
2. The average per capita income of each decile of each country is estimated using the PPP per capita GDP using the Maddison (2001) data.

3. Thus, each year's (1870 and 1920) estimate is drawn from a database of fourty observations (ten country deciles and four countries, see Table A1).

This database will allow us to see how much total inequality increased in the region as an aggregate of the changes within each country and among the four countries. This latter change derives from both changes in GDP levels and population.

When reading the results on changes in within-country inequality we have to keep in mind that the 1870 and 1920 Argentine absolute inequality levels for each province were assumed, as well as that of Uruguay in 1870. As will be discussed, the results are consistent with other proxies and we consider that our assumptions regarding inequality increase in Argentina and Uruguay are moderate.

As mentioned above, this estimate will be compared with a different estimate in which Argentine and Uruguayan within-country income distribution remains the same throughout the 1870-1920 period.

\subsection{Growth and Inequality}

\subsubsection{Growth}

The first globalization boom was characterized by very rapid economic expansion in new geographical areas. GDP growth in LASC and in the United States doubled (see Table 1) the world average and that of the twelve leading Western European countries. GDP growth in the United States was slightly above that of LASC.

The population grew faster in the LASC than in the United States due to the well-known fact that Latin European emigration took place later than North European (Hatton and Williamson 1994) and due to the «delayed» Latin American growth (Halperin Donghi 1985, 1999).

Per capita GDP growth in the United States was 30 per cent higher than that of LASC. However, the growth rate of the latter was remarkable: almost 45 per cent higher than that of the Western European countries (see Table 1) ${ }^{2}$.

Within LASC, several differences can be observed. Argentina stands out, growing faster than the others in every respect. Brazil and Uruguay experienced rapid population growth, but per capita GDP did not rise much. The population of Chile did not grow much, but a higher per capita GDP compensated for this.

2 For 1870-1913, the growth rates of the per capita GDP of Latin America and Europe were 1.8 and 1.3 , respectively. 
TABLE 1

POPULATION, GDP AND PER CAPITA GDP GROWTH OF THE SOUTHERN CONE, USA, WESTERN EUROPE AND THE WORLD, 1870 AND 1920

\begin{tabular}{|c|c|c|c|c|c|c|c|c|}
\hline & Argentina & Brazil & Chile & Uruguay & SOUTHERN CONE & USA & Western Europe (12) & World \\
\hline Population (1000) & & & & & & & & \\
\hline 1870 & 1,796 & 9,797 & 1,945 & 343 & 13,881 & 40,241 & 162,386 & $1,271.915$ \\
\hline 1920 & 8,861 & 27,404 & 3,723 & 1,371 & 41,359 & 106,881 & 223,731 & $1,791.323$ \\
\hline $\begin{array}{l}\text { Annual growth rate } \\
1870-1920\end{array}$ & 3.2 & 2.1 & 1.3 & 2.8 & 2.2 & 2.0 & 0.6 & 0.7 \\
\hline GDP* & & & & & & & & \\
\hline 1870 & 2,354 & 6,985 & 2,509 & 748 & 12,596 & 98,374 & 339,103 & $1,112,655$ \\
\hline 1920 & 30,775 & 26,393 & 10,305 & 3,666 & 71,139 & 593,438 & 739,408 & $2,732,131$ \\
\hline $\begin{array}{l}\text { Annual growth rate } \\
1870-1920\end{array}$ & 5.3 & 2.7 & 2.9 & 3.2 & 3.5 & 3.7 & 1.6 & 1.8 \\
\hline $\begin{array}{l}\text { Per capita GDP* } \\
\quad 1870\end{array}$ & 1,311 & 713 & 1,290 & 2,181 & 907 & 2,445 & 2,088 & 875 \\
\hline 1920 & 3,473 & 963 & 2,768 & 2,674 & 1,720 & 5,552 & 3,305 & 1,525 \\
\hline $\begin{array}{l}\text { Annual growth rate } \\
1870-1920\end{array}$ & 2.0 & 0.6 & 1.5 & 0.4 & 1.3 & 1.7 & 0.9 & 1.1 \\
\hline $\begin{array}{l}\text { *1990 Geary-Kham } \\
\text { Source: Maddison } \\
\text { World: } 1913 \text { instead }\end{array}$ & $\begin{array}{l}\text { dollars. } \\
03) \text {. } \\
\text { f } 1920 .\end{array}$ & & & & & & & \\
\hline
\end{tabular}


TABLE 2

THE DISTRIBUTION OF POPULATION AND INCOME AMONG THE SOUTHERN CONE COUNTRIES, 1870 AND 1920

\begin{tabular}{|l|c|c|c|c|c|}
\hline & $\begin{array}{c}\text { Population } \\
\text { share }\end{array}$ & $\begin{array}{c}\text { Mean } \\
\text { income* }\end{array}$ & $\begin{array}{c}\text { Relative } \\
\text { mean }\end{array}$ & $\begin{array}{c}\text { Income } \\
\text { share }\end{array}$ & $\begin{array}{c}\text { Log } \\
\text { (mean) }\end{array}$ \\
\hline 1870 & & & & & \\
Argentina & 0.13 & 1,311 & 1.44 & 0.19 & 7.18 \\
Brazil & 0.71 & 713 & 0.79 & 0.55 & 6.57 \\
Chile & 0.14 & 1,290 & 1.42 & 0.20 & 7.16 \\
Uruguay & 0.02 & 2,181 & 2.40 & 0.06 & 7.69 \\
\hline 1920 & & & & & \\
Argentina & 0.21 & 3,473 & 2.02 & 0.43 & 8.15 \\
Brazil & 0.66 & 963 & 0.56 & 0.37 & 6.87 \\
Chile & 0.09 & 2,768 & 1.61 & 0.14 & 7.93 \\
Uruguay & 0.03 & 2,674 & 1.55 & 0.05 & 7.89 \\
\hline
\end{tabular}

*1990 Geary-Khamis international dollars.

Source: Own estimates based on Maddison (2003).

As a result, an important shift occurred between 1870 and 1920 mainly in the Argentine and Brazilian shares of total income: while the first doubled, the latter was reduced to almost half of its previous value. What is more, Argentine income overtook that of Brazil, which had been almost triple the Argentine level in 1870. The mean income of Argentina reached almost four times that of Brazil in 1920. Chile and Uruguay also had much higher mean incomes than Brazil (Table 2).

\subsubsection{Inequality}

As shown in Table 3, almost all the comparable measures that have been reported indicate that inequality grew in the Southern Cone during the first globalization boom. The so-called Kuznets coefficients report a coherent picture of increasing inequality. In all cases, the relationship between the income share of a poorer percentile of the population and a richer one shows changes to the detriment of the poorer. An alternative estimate shows similar aggregate results (also shown in Table 3).

According to Table 4, the distribution of income in all the countries worsened. The clearest cases are those of Brazil and Chile for which we have better estimates. The increasing inequality in Argentina and Uruguay is not surprising, as the values were assigned (except for Uruguay 1920). In our defense we argue that all the other available income distribution proxies confirm the existence of worsening inequality (see the next section). In the 
TABLE 3

DISTRIBUTION MEASURES FOR THE SOUTHERN CONE, 1870 AND 1920

With increasing income distribution in Argentina and Uruguay between 1870 and 1920

\begin{tabular}{|l|c|c|c|c|}
\hline & $\mathbf{p 9 0 / p 1 0}$ & $\mathbf{p 9 0 / p 5 0}$ & $\mathbf{p 1 0 / p 5 0}$ & $\mathbf{p 7 5 / p 2 5}$ \\
\hline 1870 & 24.63 & 6.83 & 0.28 & 5.32 \\
\hline 1920 & 36.52 & 6.32 & 0.17 & 5.86 \\
\hline & GE (0) & GE (1) & Gini & \\
\hline 1870 & 0.639 & 0.594 & 0.575 & \\
\hline 1920 & 0.897 & 0.821 & 0.653 & \\
\hline
\end{tabular}

With unchanged within-province income distribution in Argentina and unchanged income distribution in Uruguay between 1870 and 1920

\begin{tabular}{|l|c|c|c|c|}
\hline & GE (0) & GE (1) & Gini & \\
\hline 1870 & 0.670 & 0.637 & 0.588 & \\
\hline
\end{tabular}

Source: Own estimates.

TABLE 4

INCOME INEQUALITY INDICES OF THE SOUTHERN CONE, 1870 AND 1920

\begin{tabular}{|l|c|c|c|c|c|c|c|}
\hline & \multicolumn{3}{|c|}{ Country indices } & \multicolumn{2}{c|}{ Within-country } & \multicolumn{2}{c|}{ Between-county } \\
\hline & GE (0) & GE (1) & Gini & GE (0) & GE (1) & GE (0) & GE (1) \\
\hline 1870 & & & & 0.587 & 0.537 & 0.052 & 0.057 \\
Argentina & 0.513 & 0.477 & 0.522 & & & & \\
Brazil & 0.581 & 0.534 & 0.548 & & & & \\
Chile & 0.715 & 0.643 & 0.594 & & & & \\
Uruguay & 0.421 & 0.397 & 0.481 & & & & \\
\hline 1920 & & & & 0.721 & 0.640 & 0.176 & 0.180 \\
Argentina & 0.654 & 0.595 & 0.574 & & & & \\
Brazil & 0.725 & 0.651 & 0.597 & & & & \\
Chile & 0.886 & 0.776 & 0.641 & & & & \\
Uruguay & 0.618 & 0.565 & 0.562 & & & & \\
\hline
\end{tabular}

Source: Own estimates.

case of Argentina we can also argue that we are underestimating the differences arising from uneven per capita GDP growth in different provinces. By keeping relative per capita GDP at the province level constant, we are only 
capturing inequality differences arising from uneven population growth, but not from uneven per capita GDP growth. Much evidence points to the fact that Buenos Aires and the provinces of the Pampa Gringa (especially Santa Fe and Córdoba), as well as Mendoza and Tucumán, grew at faster rates than other less developed regions.

Table 4 also shows the results for the part of inequality that can be explained within the countries and the part arising from differences between the countries. The worsening in income distribution was explained in similar proportions by both types of inequality (it varies slightly depending on the index used). However, it was between-country inequality that grew more, that is, the different rates at which the different countries grew had a higher impact on total inequality than changes in domestic inequality. Of course, this may be the result of an underestimation of inequality growth in Argentina and Uruguay.

A comparison between our results and those of Bourguignon and Morrisson (2002) yields the following conclusions:

1. Bourguignon and Morrisson's (2002) Gini coefficient for Latin America can be estimated as 0.561 both in 1870 and 1910; the weighted average of our country Gini coefficients for the LASC countries (compared to Table 3, between-country inequality is not taken into account) is 0.549 in 1870 and 0.595 in 1920.

2. Compared to other regions, the LASC levels look high in both years: Africa 0.336, Asia 0.475, Australia-Canada-New Zealand 0.438 (all in 1870 and 1910) and finally the United Kingdom-Ireland 0.508 in 1870 and 0.485 in 1910 .

In short, by 1870 Latin America's inequality was particularly high relative to other regions and this relative position worsened further during the following half century.

\subsubsection{Inequality and per capita GDP levels on the eve of globalization}

In previous estimates of Brazilian inequality in 1872 the low levels obtained were very surprising (Bértola et al. 2009), as Brazil is nowadays one of the most unequal societies in the world. The results shown in this paper are much higher and look more reliable.

When reflecting on the low inequality levels of Brazil in 1872, we found an interesting framework in Milanovic et al. (2007). Their basic idea is that the level of possible inequality, the IPF, in their words, depends on the level of per capita income, the subsistence level for the majority of the population and the size of the elite that can appropriate the eventual surplus. They present a final equation as follows:

$$
G^{*}=((\alpha-1) / \alpha)(1-\varepsilon),
$$


FIGURE 2

THE INEQUALITY FRONTIER CURVE

Ancient Inequalities: Estimated Gini Coefficients, and Two Inequality Possibility Frontiers

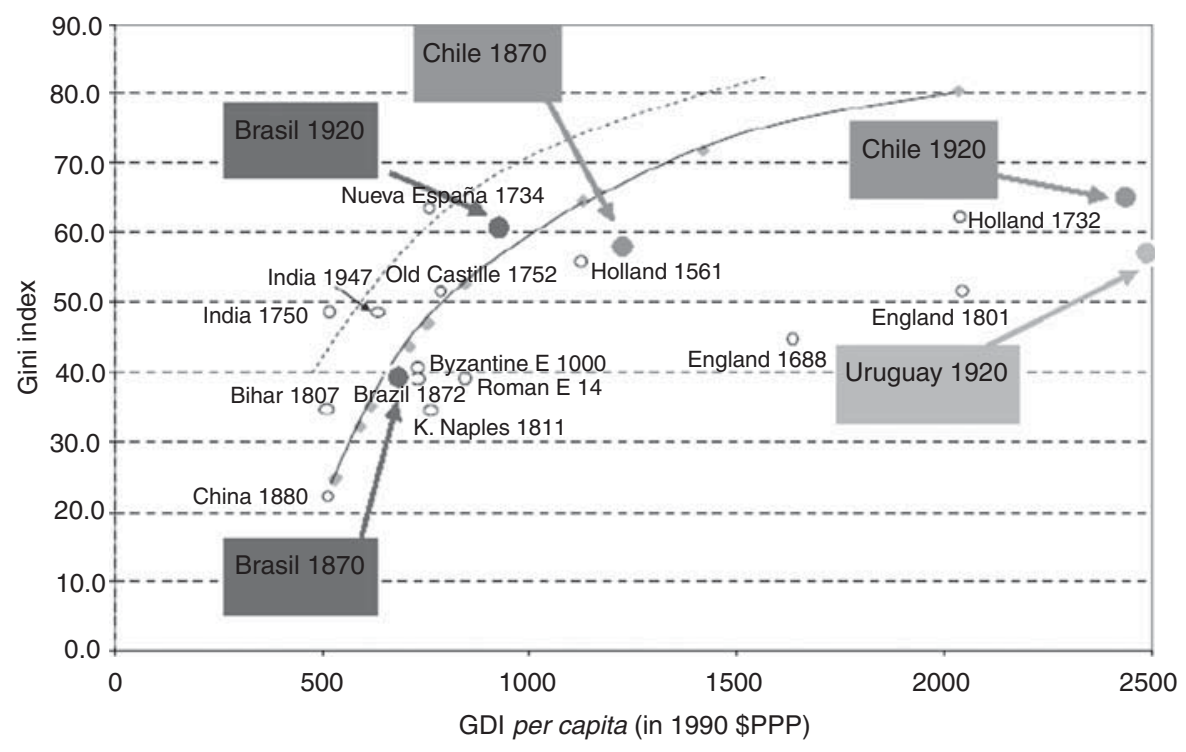

Note: The solid line IPF is constructed on the assumption that $\mathrm{s}=\$ \mathrm{PPP} 400$; the broken-line IPF is constructed on the assumption that $s=\$ P P P 300$. Estimated Ginis are Ginis 2 unless only Gini1 is available.

Source: Milanovic et al. (2007) and own estimates.

where $G^{*}$ is the IPF for a certain level of per capita income, $\varepsilon$ is the proportion of people belonging to a very small upper class and $\alpha$ is the relationship between average income and subsistence income. In other words, an economy at a very low level of development, in which average income is not much higher than subsistence level, does not produce a surplus large enough to allow for high inequality levels.

The authors present a theoretical IPF curve, assuming that the elite is 0.1 per cent of the population and that subsistence income is 300 or 400 international PPP dollars (the latter figure is used by Maddison as an historical benchmark).

Their results are plotted in Figure 2, along with our previous values. If we introduced Brazil's mean income into Milanovic et al.'s (2007) equation, we should obtain a very good fit of our estimate to the curve, showing that Brazil was, both in 1872 and in 1920, almost on the IPF curve; the Brazilian elites were extracting from the working population all potential surplus and inequality was relatively low. These results are important as they could, for 
instance, mean that high inequality in Brazil was not a structural feature, but was related to the first globalization boom.

However, there are many misleading assumptions there.

In Table A2 we present three panels.

Panel A presents Milanovic et al's estimates with our Gini coefficients. As we saw, our previous estimate for Brazilian inequality lay almost on the curve. However, our data indicate that 400 PPP\$ is not a correct estimate of subsistence level. Our data tell us that the lowest Brazilian decile in 1872 had an average income of nearly 60 PPP\$. Using our 1870 Brazilian Gini with 400 PPP\$ means that the elite was extracting more income than available.

In panel B, Maddison's subsistence level estimates are substituted by our own as represented by the average income of the first decile in 1990 PPP\$. According to this figure, potential inequality was much higher than real inequality, with an extraction rate of 64 per cent on average.

Finally, panel C replicates panel A, but using our current estimates of average and subsistence income for Brazil and Chile, in 1870 and 1920. These results look interesting and much more reliable as we avoid using Maddison's 1990 PPP\$.

According to panel C, the Brazilian slave society in 1872 had a rather high extraction rate of 0.83 of potential or frontier inequality. The Chilean haciendabased economy had an even higher extraction rate of 0.89 . While the Brazilian extraction rate fell to 0.73 in 1920 (the income of the elites is probably underestimated in 1920), the Chilean rate remained similar to its 1872 level.

We can thus conclude that our estimates showing relatively high inequality levels in Brazil and Chile in 1870 are compatible with the Milanovic et al.'s (2007) approach to the IPF. In other words, these societies were rich enough to allow for high inequality levels before the first globalization boom had a strong impact on them.

We think that there is enough evidence to sustain the view that inequality was structurally high in Brazil and Chile. There is, however, less evidence for Uruguay and the Buenos Aires region.

What about Williamson's statement that Latin America was not particularly unequal, that is, that Latin America was not more unequal than Europe, for example? First, Williamson's comparisons require a more careful discussion of the databases used. The results are very volatile depending on which cases we take into consideration, and the number of cases is very small. Furthermore, from our point of view the most important question is not whether Latin American inequality was higher than European inequality, but rather why high inequality remained as a structural feature in Latin America, and why Europe was able to reverse its high inequality during the $20^{\text {th }}$ century. What really matters is not the Gini coefficient, but the underlying economic and social forces and dynamics that result in those coefficients and reproduce the patterns of income distribution. In considering these dynamics international inequality is also important as it reflects the competitiveness of the different economies 
and the opportunities for productivity growth and structural change. Williamson's own figures show that the Latin American extraction rate is higher than that of Europe and these results seem to be reinforced by our own estimates. Besides, Williamson points to an important fact: European development was far from a rosy picture in which income inequality decreased steadily due to the growth of good institutions that promoted open political and economic access to ownership of land, physical and human capital. International inequality was steadily growing at the same time. Finally, the fact that inequality was growing during the first globalization boom is not in contradiction with the idea of the existence of structural inequality.

\section{INEQUALITY, INSTITUTIONS AND GLOBALIZATION, 1870-1920}

The first globalization boom was mainly driven by technological and organizational changes in the transport sector, both maritime and land. The reduction of real freight prices was impressive: the North freight rate index for American export routes dropped by more than 41 per cent in real terms between 1870 and 1910 (North 1958), while the British index fell by about 70 per cent between 1840 and 1910 (Williamson 2002).

However, in the case of LASC, the impact was somewhat lower; average freight costs between Montevideo and Liverpool fell annually by 0.7 per cent between 1870 and 1913 (Bértola 2000, Table 4.1, p. 102). Juan Stemmer (1989), however, has shown that overseas freight rates fell much less in the case of the southward leg than in that of the northward leg (p. 24). This means that bulky South American exports benefited more from freight reductions than more valuable imports per unit of weight.

Even railroads made their contribution to the reduction of economic distances. In the case of the small Uruguayan territory, between the 1870s and 1913, railroad tariffs decreased by 3.1 times annually (Bértola 2000, Table 4.1, p. 102). This fall in prices has to be added to the relative cost reduction between railroads and traditional means of transport.

The immediate consequence of these transport price reductions was the improvement in the competitiveness of Latin American production on the basis of the exploitation of natural resources. As the world became smaller in economic terms, new areas could compete at an advantage, meeting an increasing demand on world markets, driven by rapid per capita income growth and industrialization in Europe. In addition, the fast domestic growth of the United States was consuming an increasing share of the United States's agrarian surplus.

The agrarian frontier advanced at high rates due to lower transport costs, mainly on the Atlantic coast of LASC, but also in the north and south of Chile. In the case of Argentina, a country with an extensive open frontier, the land-labor index moved from 29 to 100 between 1883 and 1911 (Williamson 2002, Table A3) in spite of the very rapid population growth. The same 
situation affected Brazil, where the leading region was the southeast, which experienced its own "conquest of the West», and South. The smaller Uruguay, on the other hand, without an open frontier to occupy, saw the number of people per hectare double from 1883 to 1911.

A similar trend can be found in the core of the Buenos Aires region. The expansion of the frontier implied major changes in the distribution of the population in the territory and subsequently in the distribution of income, depending on the relative per capita income of each region. The Argentine Pampas grew very rapidly in relation to the less dynamic inland. The population of the Pampa Gringa and Buenos Aires increased from 60 to 80 per cent of the total population.

Chile was not an exception and expanded its frontier both toward the South and the North, especially after the War of the Pacific. The northern region was rich in nitrates, copper and guano. The Chilean case is interesting in the sense that frontier expansion led to decreasing inequality. Following Rodríguez Weber (2009) and Bertola and Rodríguez Weber (2009), three distinct trends in income inequality can be found between 1860 and 1930 .

"In short, by the mid-19th century, Chile showed a high concentration of wealth, political power and income. The hacienda system of colonial origin that predominated was rather archaic. The first impact of globalization on Chile was to strengthen the power of the elite, making income distribution less equal. The expansion of the frontier initiated a process of social change on the periphery of the Chilean economy, improving the income distribution. However, the core of the old system remained alive and controlled the policies enacted by the State. During the first decades of the 20th century, while GDP growth rates decreased, the Chilean economy became more dependent on international prices. The distribution of income worsened considerably due to rising domestic prices, shifting the distribution of power and wealth in favor of the elite... (The Chilean pattern of development during the First Globalization Boom) did not generate a productive structure particularly conducive to technological change and to dynamic and egalitarian social advances. On the contrary, strong links with the world economy, while promoting structural change and expansion into new territories, preserved archaic social structures that inhibited further growth: la longue durée appeared under new forms.» (Bertola and Rodríguez Weber 2009, p. 23)

In Brazil, as shown in Table 5, the stagnating and poor Northeast lost ground to the dynamic South and Southeast, both in terms of both population share and average per capita income. The income share of the South and Southeast increased from 58 to 67 per cent following a similar increase in population. However, in Brazil, between-region inequality did not grow 
TABLE 5

BRAZILIAN INCOME INEQUALITY, 1872 AND 1920

\begin{tabular}{|c|c|c|c|c|c|c|c|c|}
\hline \multirow[b]{2}{*}{ Region } & \multicolumn{2}{|c|}{ Population share } & \multicolumn{2}{|c|}{ Income share } & \multicolumn{2}{|c|}{ Mean income } & \multicolumn{2}{|c|}{ Relative mean } \\
\hline & 1872 & 1920 & 1872 & 1920 & 1872 & 1920 & 1872 & 1920 \\
\hline Center West & 2.6 & 2.7 & 1.7 & 3.1 & 128 & 3179 & 0.65 & 1.20 \\
\hline North & 3.3 & 5.3 & 4.9 & 4.2 & 291 & 2084 & 1.46 & 0.79 \\
\hline Northeast & 48.0 & 37.4 & 35.1 & 25.7 & 145 & 1817 & 0.73 & 0.68 \\
\hline South & 8.1 & 11.2 & 11.8 & 16.3 & 290 & 3824 & 1.46 & 1.44 \\
\hline \multirow{3}{*}{ Southeast } & 38.0 & 43.4 & 46.5 & 50.7 & 243 & 3092 & 1.22 & 1.16 \\
\hline & \multicolumn{3}{|c|}{1872} & & & & & \\
\hline & GE (0) & GE (1) & Gini & & & & & \\
\hline Center West & 0.627 & 0.751 & 0.597 & & & & & \\
\hline North & 0.346 & 0.523 & 0.443 & & & & & \\
\hline Northeast & 0.351 & 0.433 & 0.460 & & & & & \\
\hline South & 0.418 & 0.521 & 0.495 & & & & & \\
\hline \multirow[t]{3}{*}{ South-East } & 0.745 & 1.546 & 0.640 & & & & & \\
\hline & \multicolumn{3}{|c|}{1920} & & & & & \\
\hline & GE (0) & GE (1) & Gini & & & & & \\
\hline Center West & 0.701 & 1.067 & 0.624 & & & & & \\
\hline North & 0.516 & 0.808 & 0.545 & & & & & \\
\hline Northeast & 0.637 & 1.027 & 0.595 & & & & & \\
\hline South & 0.627 & 0.958 & 0.595 & & & & & \\
\hline \multirow[t]{2}{*}{ South-East } & 0.617 & 0.891 & 0.593 & & & & & \\
\hline & \multicolumn{3}{|c|}{ Within-region } & & & & & \\
\hline 1872 & 0.513 & 0.971 & & & & & & \\
\hline \multirow[t]{2}{*}{1920} & 0.623 & 0.939 & & & & & & \\
\hline & \multicolumn{3}{|c|}{ Between-region } & & & & & \\
\hline 1872 & 0.041 & 0.040 & & & & & & \\
\hline 1920 & 0.039 & 0.038 & & & & & & \\
\hline
\end{tabular}

Source: Bértola et al. (2009).

Regions:

Center-West: Goyaz and Mato Grosso.

North: Amazonas, Pará and Territorio do Acre.

North-East: Alagoas, Bahía, Ceará, Maranhao, Parahyba, Pernambuco, Piahuy, Río Grande do Norte and Sergipe.

South: Paraná, Río Grande do Sul and Santa Catarina.

South-East: Espiritu Santo, Minas Gerais, Río de Janeiro and São Paulo. 
significantly. It seems that changes took place inside each region, as, for example, the change of roles between São Paulo and RJ in the Southeast. In any case our estimates are still weak so we cannot be really sure about the real magnitude of increasing inequality. At the same time, other important changes that affect inequality that are not fully captured by income inequality have to be kept in mind. The abolition of slavery was such a change, along with increasing immigration of Europeans to certain regions and the expansion of Brazil's many frontiers. Probably then, the increase in Brazilian inequality was not as high as that presumed by the globalization approach. In any case, Brazil was and remains a highly unequal society.

Regional inequality also depends on the so-called commodity lottery. Economic growth was strongly dependent on the availability of natural resources. Moreover, economic growth depended on how demand, prices and international competition changed in these different commodity markets. In Bértola and Williamson (2006), these features were analyzed from the point of view of the international commodity markets and the dominant labor markets in these commodity markets. The Argentine Pampas, Uruguay and Southern Brazil produced similar commodities to those produced in the core countries by high-income peasants, who set a high marginal price for their products, due to the high price of land. Countries producing tropical crops in competition with labor-abundant economies could hardly be competitive if they payed high wages unless some kind of monopolistic position was taken, as in the case of the coffee plantations in Brazil. The production of minerals used to be highly concentrated in space and faced varying degrees of market competition. The commodity lottery was thus favorable for temperate regions such as those of the Río de la Plata, for the almost monopolistic coffee production in Brazil and for Chilean nitrates. However, the rubber plantations of Northern Brazil, for example, faced drastic changes in international competitiveness, first challenged by Indonesian production and later by synthetic rubber.

\section{SUMMARY OF FINDINGS}

In this paper we present a first generation of direct estimates of income inequality in the LASC countries. The evidence that is presented is of varied quality, including relatively good estimates for Brazil, Chile and, in part, for Uruguay, combined with some assumptions regarding Gini coefficients for Argentina (1870 and 1920) and Uruguay (1870).

One conclusion is that, at least in the cases of Brazil and Chile, inequality seemed to be high on the eve of the first globalization boom and it was clearly associated with social relations and institutions of colonial origin. These estimates of high inequality levels are consistent with the IPF approach. There is now good information for the settler economies of the Rio de la 
Plata, where the presence of colonial institutions may have been less important, although not absent.

Inequality was likely to increase between 1870 and 1920. This increase was the result of many different forces:

1. Population increased at different rates and grew more in countries and regions with higher average per capita income.

2. Per capita income grew at different rates in different countries. Income and population in high-income Argentina grew faster than in populous Brazil.

3. The combination of these first two factors resulted in significant increases in between-country inequality, which contributed to half of the total increase in inequality in LASC as a whole.

4. The evidence of increased inequality in Brazil and Chile, and probably also in Argentina and Uruguay, is supported by complementary proxies for income inequality, such as land-labor ratios, per capita GDP-real wage ratios and terms of trade. This trend was present in every Brazilian region, except the Southeast, already a particularly unequal region by 1870 .

5. In the case of Brazil, the increase in inequality is not very large and several contradictory movements may be observed. The $\mathrm{H}-\mathrm{O}$ approach may predict increasing inequality in core regions but the frontier expanded significantly. Some old colonial regions, like Bahía and RJ, lost their relative advantages to new frontier regions like the South and the state of SP. The commodity lottery also contributed to uneven development among different regions, the North being an example of the collapse related to borracha exports. Last, but not least, the abolition of slavery ( 25 per cent of the active population in 1872), along with important European immigration, produced important changes. More research is needed to address the real importance of these different factors. However, the picture is not that of radically increasing inequality from a poor and less unequal point of departure.

6. The Chilean case is also one in which total inequality did not grow extraordinarily. Departing from high inequality levels, globalization first increased inequality as it reinforced the archaic social structure of the hacienda system. Once the commodity lottery produced the wheat export crisis, the elite in control of the state led Chile into the Pacific War and succeeded in doubling Chile's territory. New social relations and institutions in frontier regions produced a reduction of inequality until the new terms of the trade boom at the beginning of the $20^{\text {th }}$ century, once again associated with the strengthened social relations linked to the hacienda system, contributed to a new wave of inequality.

7. The first globalization boom left the LASC countries with greater differences among them than before. However, within certain limits, 
they all shared the presence of high-income inequality linked to the strengthened position of the landed, mining, merchant and political elites. This was due to the pattern of productive specialization, mainly oriented toward the exploitation of natural resources and exhibiting limited capacity to innovate and produce technical change. The prospects for continued growth were poor, especially when world commodity markets collapsed.

\section{REFERENCES}

Acemoglu, D.; Johnson, S., and Robinson, J. (2002): «Reversal of Fortune: Geography and Institutions in the Making of the Modern World Income Distribution». Quarterly Journal of Economics 117 (4), pp. 1231-1294.

Acemoglu, D.; Johnson, S., and Robinson, J. (2005): «Institutions as the Fundamental Cause of Long-Run Growth», in P. Aghion and S. N. Durlauf (eds), Handbook of Economic Growth. The Netherlands: Elsevier B.V., pp. 385-472.

Álvarez, J. (2007): «Distribución del Ingreso e Instituciones: Nueva Zelanda y Uruguay en el Largo Plazo», en J. Álvarez, L. Bértola y G. Porcile (eds), Primos Ricos y Empobrecidos: Crecimiento, Distribución del Ingreso e Instituciones en AustraliaNueva Zelanda vs. Argentina-Uruguay. Montevideo: Editorial Fin de Siglo, pp. 273-303.

Álvarez, J.; Bértola, L., and Porcile, G. (2007): Primos ricos y empobrecidos: Crecimiento, distribución del ingreso e instituciones en Australia-Nueva Zelanda vs Argentina-Uruguay. Montevideo: Editorial Fin de Siglo.

Bauer, A. (1986): «Rural Spanish America, 1870-1930», in L. Bethel (ed.), Cambridge History of Latin America IV. New York: Cambridge University Press, pp. 151-186.

Bértola, L. (2000): Ensayos de Historia Económica: Uruguay en la Región y el Mundo. Montevideo, Trilce.

Bértola, L. (2005): «A 50 años de la Curva de Kuznets: Crecimiento y Distribución del Ingreso en Uruguay y otras Economías de nuevo Asentamiento Desde 1870». Investigaciones en Historia Económica 3, pp. 135-176.

Bértola, L. (2010): "Institutions and the Historical Roots of Latin American Divergence», in J. A. Ocampo and J. Ross (eds), forthcoming in the Handbook of Latin American Economics. New York: Oxford University Press.

Bértola, L.; Castelnovo, C.; Rodríguez Weber, J., and Willebald, H. (2009): «Income Distribution in the Latin American Southern Cone during the First Globalization Boom and Beyond». International Journal of Comparative Sociology, V 50 (5-6), pp. 452-485.

Bertola, L., and Rodríguez Weber, J. (2009): «Between Le Longue Durée, Globalization and the Expansion of the Frontier: Income Inequality in Chile 1860-1930». Paper Presented at the Conference A Comparative Approach to Inequality and Development: Latin America and Europe, Madrid, May.

Bértola, L., and Williamson, J. (2006): «Globalization in Latin America before 1940», in V. Bulmer-Thomas, J. Coatsworth, and R. Cortés Conde (eds), The Cambridge Economic History of Latin America, vol. II. New York: Cambridge University Press, pp. 11-56.

Bourguignon, F., and Morrisson, C. (2002): «Inequality among World Citizens». American Economic Review 92 (4), pp. 727-744. 
Bulmer-Thomas, V. (1994): The Economic History of Latin America Since Independence. Cambridge: Cambridge University Press.

Cardoso, F. H., and Faletto, E. (1969): Dependencia y desarrollo en América Latina. Mexico City: Sigio XXI Editores.

Cardoso, C. F. S., and Pérez Brignoli, H. (1979): Historia Económica de América Latina, vol. I-II. Barcelona: Editorial Crítica.

COATsworth, J. (2008): "Inequality, Institutions and Economic Growth in Latin America». Journal of Latin American Studies 40, pp. 545-569.

Duncan, K., and RutLedge, I. (ed.) (1977): «Land and Labour in Latin America. Essays on the Development of Agrarian Capitalism in the Nineteenth and Twentieth Centuries», in Cambridge Latin American Studies 26. Cambridge University Press.

Engerman, S. L., and SoKoloff, K. L. (1997): «Factor Endowments, Institutions, and Differential Paths of Growth among New World Economies», in S. Haber (ed.), How Latin America Fell Behind. Essays on the Economic Histories of Brazil and Mexico, 1800-1914. Stanford: Stanford University Press, pp. 260-304.

Engerman, S. L.; Haber, S. H., and Sokoloff, K. L. (2000): «Inequality, Institutions, and Differential Paths of Growth among New World Economies», in C. Menard (ed.), Institutions, Contracts, and Organizations. Cheltenham: Edward Elgar, pp. 108-134.

FranK, A. G. (1967): Capitalism and Underdevelopment in Latin America: Historical Studies of Chile and Brazil. New York: Monthly Review Press.

Furtado, C. (1974): La Economía Latinoamericana Desde la Conquista Ibérica Hasta la Revolución Cubana. México: Siglo Veintiuno.

Gálvez, T., and Bravo, R. (1992): "Siete Décadas de Registro del Trabajo Femenino, 1854-1920». Revista Estadística \& Economía 5. Chile: Instituto Nacional de Estadísticas, pp. 1-52.

García-Jimeno, C., and Robinson, J. (2009): «The Myth of the Frontier» NBER Working paper Series no. 14774. Cambridge, MA: National Bureau of Economic Research.

Gelman, J., and Santilli, D. (2010): «Las Muchas Explicaciones de la Desigualdad: la Propiedad de la Tierra y el Crecimiento Económico de Buenos Aires Entre 1839 y 1867». Unpublished manuscript.

Glade, W. (1986): «Latin America and the International Economy, 1870-1914», in L. Bethell (ed.), The Cambridge History of Latin America: c. 1870 to 1930, vol. IV. Cambridge: Cambridge University Press.

Goldsmith, R. W. (1986): Brasil 1850-1984: Desenvolvimento Financieiro sob um Século de Inflaçao. San Pablo: Editorial Harper \& Row do Brasil Ltda.

HalPerin Donghi, T. (1985): «Economy and Society in Post-Independence Spanish America», in L. Bethell (ed.), The Cambridge History of Latin America: From Independence to c. 1870, vol. III. Cambridge: Cambridge University Press.

Halperin Donghi, T. (1999): «Historiografía Colonial y Multiculturalismo. La Historia de la Colonización entre la Perspectiva del Colonizador y el Colonizado», in M. Mengus Bornemann (ed.), Dos Décadas de Investigación en Historia Económica Comparada en América Latina. Homenaje a Carlos Sempat Assadourian. Mexico: Colegio de México, Centro de Estudios Históricos, pp. 17-60.

Harley, K. (2007): "Comments on Factor Prices and Income Distribution in less Industrialised Economies 1870-1939: Refocusing on the Frontier». Australian Economic History Review 47 (3), pp. 238-248.

Hatton, T., and Williamson, J. (1994): "Latecomers to Mass Emigration: the Latin Experience», in T. Hatton and J. Williamson (eds), Migration and the International Labor Market 1850-1939. Oxon: Routledge, pp. 55-71. 
Klein, H. (1995): «A Participação Política no Brasil do Século XIX: os Votantes Em São Paulo em 1880». DADOS - Revista de Ciências Sociais 38 (3), pp. 527-544.

KuZNETS, S. (1955): "Economic Growth and Income Inequality». American Economic Review XLV (1), pp. 1-28.

Landes, D. (1998): The Wealth and Poverty of Nations. New York: Norton.

Llach, L (2004): "The Wealth of the Provinces: Unequal Federalism, Economic Policy and Crisis in Argentina, 1880-1890». Mimeo, Harvard University.

Maddison, A. (2001): The Word Economy: A Millennial Perspective. Paris: Development Centre Studies, Organization for Economic Cooperation and Development.

Maddison, A. (2003): The World Economy. Historical Statistics. Paris: OECD.

Milanovic, B.; Lindert, P., and Williamson, J. (2007): "Measuring Ancient Inequality», Policy Research. The World Bank Development Research Group Poverty Team Working Paper Series no. 4412.

Monteiro, J. M. (2006): «Labor Systems», in V. Bulmer-Thomas, J. Coatsworth, and R. Cortés Conde (eds), The Cambridge Economic History of Latin America, vol. I. Cambridge University Press, pp. 185-233.

Newson, L. (2006): «The Demographic Impact of Colonization», in V. Bulmer-Thomas, J. Coatsworth, and R. Cortés Conde (eds), The Cambridge Economic History of Latin America, vol. I. New York: Cambridge University Press, pp. 143-184.

North, D. C. (1958): «Ocean Freight Rates and Economic Development 1750-1913». Journal of Economic History 18 (December), pp. 538-555.

North, D. C.; Weingast, B., and Summerhill, W. (2000): «Order, Disorder and Economic Change. Latin America versus North America», in B. Bueno de Mesquita, and Hilton L. Root (eds), Governing for Prosperity. New Haven: Yale University Press, pp. 17-58.

Nunes, N. F. M. (2003): "A Experiência em Campos dos Goytacazes (1870-1889): Freqüência Eleitoral e Perfil da População Votante». DADOS - Revista de Ciências Sociais 46 (2), pp. 311-343. Río de Janeiro.

O'Rourke, K. H., and Williamson, J. G. (1999): Globalization and History. Cambridge, Mass: MIT Press.

O'Rourke, K. H., and Williamson, J. G. (2005): «From Malthus to Ohlin: Trade, Industrialization and Distribution since 1500». Journal of Economic Growth 10, pp. 5-34.

Prados De La Escosura, L. (2005): "Growth, Inequality, and Poverty in Latin America: Historical Evidence, Controlled Conjectures». Economic History and Institutions Series Working Paper no. 05-41(04). Madrid: Departamento de Historia Económica e Instituciones, Universidad Carlos III.

Prados De La Escosura, L. (2007): «Inequality and Poverty in Latin America: A Long-Run Exploration», in T. J. Hatton, K. H. O'Rourke, and A. M. Taylor (eds) The New Comparative Economic History. Cambridge, MA: MIT Press, pp. 291-315.

Robinson, J. (2006): «El Equilibrio de América Latina», in N. Botana, and F. Fukuyama (eds), La Brecha entre América Latina y Estados Unidos. Buenos Aires: Fondo de Cultura Económica, pp. 197-230.

Rodríguez Weber, J. (2009): «Los Tiempos de la Desigualdad. La Distribución del Ingreso en Chile 1860-1930», Master Thesis in Economic History, Uruguay: Facultad de Ciencias Sociales, Universidad de la República.

Stein, S. J., and Stein, B. H. (1970): The Colonial Heritage of Latin America. Essays on Economic Dependence in Perspective. New York: Oxford University Press.

Stemmer, J. E. O. (1989): «Freight Rates in the Trade between Europe and South America». Journal of Latin American Studies 21 (part 1), pp. 22-59.

Sunkel, O., and Paz, P. (1982): El Subdesarrollo Latinoamericano y la Teoría del Desarrollo. (16a). México: Editorial Siglo Veintiuno. 
Thorp, R. (1986): «Latin America and the International Economy from the First World War to the World Depression», in L. Bethell (ed.), Cambridge History of Latin America $I V$, pp. 57-81.

Willebald, H. (2007): «Desigualdad y especialización en el crecimiento de las economías templadas de nuevo asentamiento, 1870-1940». Revista de Historia Económica, Journal of Iberian and Latin American Economic History 25 (2), pp. 291-345.

Williamson, J. G. (1995): «The Evolution of Global Markets since 1830: Background Evidence and Hypotheses». Explorations in Economic History 32, pp. 141-196.

Williamson, J. G. (1999): «Real Wage Inequality and Globalization in Latin America before 1940». Revista de Historia Económica XVII (special issue), pp. 101-142.

Williamson, J. G. (2000): «Land, Labor and Globalization in the Pre-Industrial Third World». NBER Working Paper Series 7784. Cambridge, MA: National Bureau of Economic Research.

Williamson, J. G. (2002): «Land, Labor, and Globalization in the Third World, 1870-1940». Journal of Economic History 62 (1), pp. 55-85. 


\section{APPENDIX}

TABLE A1

POPULATION AND PER CAPITA INCOME BY DECILES IN THE SOUTHERN CONE COUNTRIES, 1870 AND 1920 (1990 GEARY-KHAMIS DOLLARS)

\begin{tabular}{|c|c|c|c|c|}
\hline & \multicolumn{2}{|c|}{1870} & \multicolumn{2}{|c|}{1920} \\
\hline Country & NBER & Income & NBER & Income \\
\hline Argentina & 179,600 & 237 & 886,100 & 248 \\
\hline Argentina & 179,600 & 405 & 886,100 & 523 \\
\hline Argentina & 179,600 & 545 & 886,100 & 799 \\
\hline Argentina & 179,600 & 689 & 886,100 & 1,121 \\
\hline Argentina & 179,600 & 852 & 886,100 & 1,519 \\
\hline Argentina & 179,600 & 1,045 & 886,100 & 2,039 \\
\hline Argentina & 179,600 & 1,292 & 886,100 & 2,767 \\
\hline Argentina & 179,600 & 1,638 & 886,100 & 3,893 \\
\hline Argentina & 179,600 & 2,213 & 886,100 & 6,012 \\
\hline Argentina & 179,600 & 4,189 & 886,100 & 15,811 \\
\hline Brazil & 979,700 & 61 & $2,740,400$ & 58 \\
\hline Brazil & 979,700 & 124 & $2,740,400$ & 126 \\
\hline Brazil & 979,700 & 185 & $2,740,400$ & 198 \\
\hline Brazil & 979,700 & 255 & $2,740,400$ & 282 \\
\hline Brazil & 979,700 & 339 & $2,740,400$ & 389 \\
\hline Brazil & 979,700 & 448 & $2,740,400$ & 530 \\
\hline Brazil & 979,700 & 597 & $2,740,400$ & 730 \\
\hline Brazil & 979,700 & 824 & $2,740,400$ & 1,046 \\
\hline Brazil & 979,700 & 1,240 & $2,740,400$ & 1,653 \\
\hline Brazil & 979,700 & 3,056 & $2,740,400$ & 4,619 \\
\hline Chile & 194,457 & 79 & 372,260 & 114 \\
\hline Chile & 194,457 & 173 & 372,260 & 269 \\
\hline Chile & 194,457 & 269 & 372,260 & 440 \\
\hline Chile & 194,457 & 383 & 372,260 & 652 \\
\hline Chile & 194,457 & 526 & 372,260 & 929 \\
\hline Chile & 194,457 & 716 & 372,260 & 1,308 \\
\hline
\end{tabular}


TABLE A1 (Continued)

\begin{tabular}{|l|c|c|c|c|}
\hline & \multicolumn{2}{|c|}{$\mathbf{1 8 7 0}$} & \multicolumn{2}{c|}{ 1920 } \\
\hline Country & NBER & Income & NBER & Income \\
\hline Chile & 194,457 & 985 & 372,260 & 1,866 \\
\hline Chile & 194,457 & 1,408 & 372,260 & 2,778 \\
\hline Chile & 194,457 & 2,218 & 372,260 & 4,612 \\
\hline Chile & 194,457 & 6,145 & 372,260 & 14,715 \\
\hline Uruguay & 34,300 & 556 & 137,100 & 209 \\
\hline Uruguay & 34,300 & 869 & 137,100 & 432 \\
\hline Uruguay & 34,300 & 1,109 & 137,100 & 653 \\
\hline Uruguay & 34,300 & 1,347 & 137,100 & 907 \\
\hline Uruguay & 34,300 & 1,604 & 137,100 & 1,219 \\
\hline Uruguay & 34,300 & 1,898 & 137,100 & 1,623 \\
\hline Uruguay & 34,300 & 2,261 & 137,100 & 2,183 \\
\hline Uruguay & 34,300 & 2,748 & 137,100 & 3,043 \\
\hline Uruguay & 34,300 & 3,520 & 137,100 & 4,643 \\
\hline Uruguay & 34,300 & 5,895 & 137,100 & 11,828 \\
\hline
\end{tabular}

TABLE A2

ESTIMATED GINI COEFFICIENTS AND THE INEQUALITY POSSIBILITY FRONTIER FOR THE SOUTHERN CONE COUNTRIES, 1870 AND 1920

\begin{tabular}{|c|c|c|c|c|c|c|c|}
\hline & $\begin{array}{l}\text { \%G-real/ } \\
\text { IPF }\end{array}$ & G-real & IPF & & $\begin{array}{c}\% \\
\text { Elite }\end{array}$ & $\begin{array}{c}\text { Mean } \\
1990 \\
\text { PPP\$\$ }\end{array}$ & $\begin{array}{l}\text { Maddison } \\
1990 \text { PPP\$ }\end{array}$ \\
\hline & & & & $\alpha$ & $\varepsilon$ & $\mu$ & $\mathbf{s}$ \\
\hline \multicolumn{8}{|c|}{ Panel A: Elite as $0.1 \%$ of the population and subsistence income at $400 \mathrm{PPP} \$$} \\
\hline \multicolumn{8}{|l|}{ Argentina } \\
\hline 1872 & 0.75 & 0.52 & 0.69 & 3.28 & 0.1 & 1,311 & 400 \\
\hline 1920 & 0.65 & 0.57 & 0.88 & 8.68 & 0.1 & 3,473 & 400 \\
\hline \multicolumn{8}{|l|}{ Brazil } \\
\hline 1872 & 1.27 & 0.56 & 0.44 & 1.80 & 0.1 & 721 & 400 \\
\hline 1920 & 1.02 & 0.60 & 0.58 & 2.41 & 0.1 & 963 & 400 \\
\hline \multicolumn{8}{|l|}{ Chile } \\
\hline 1870 & 0.86 & 0.59 & 0.69 & 3.23 & 0.1 & 1,290 & 400 \\
\hline 1920 & 0.75 & 0.64 & 0.85 & 6.92 & 0.1 & 2,768 & 400 \\
\hline
\end{tabular}


TABLE A2 (Continued)

\begin{tabular}{|c|c|c|c|c|c|c|c|}
\hline \multicolumn{8}{|l|}{ Uruguay } \\
\hline 1872 & 0.59 & 0.48 & 0.82 & 5.45 & 0.1 & 2,181 & 400 \\
\hline 1920 & 0.66 & 0.56 & 0.85 & 6.68 & 0.1 & 2,674 & 400 \\
\hline \multicolumn{8}{|l|}{ Averages } \\
\hline 1872 & 0.87 & & & & & & \\
\hline 1920 & 0.77 & & & & & & \\
\hline Total & 0.82 & & & & & & \\
\hline \multicolumn{8}{|c|}{ Panel B: Own subsistence levels estimates (average of the lowest decile) } \\
\hline \multicolumn{8}{|l|}{ Argentina } \\
\hline 1872 & 0.68 & 0.52 & 0.77 & 5.52 & 0.1 & 1,311 & 300 \\
\hline 1920 & 0.62 & 0.57 & 0.93 & 14.03 & 0.1 & 3,473 & 248 \\
\hline \multicolumn{8}{|l|}{ Brazil } \\
\hline 1872 & 0.62 & 0.56 & 0.91 & 4.71 & 0.1 & 721 & 61 \\
\hline 1920 & 0.64 & 0.60 & 0.94 & 16.65 & 0.1 & 963 & 58 \\
\hline \multicolumn{8}{|l|}{ Chile } \\
\hline 1870 & 0.63 & 0.59 & 0.94 & 16.27 & 0.1 & 1,290 & 79 \\
\hline 1920 & 0.67 & 0.64 & 0.96 & 24.29 & 0.1 & 2,768 & 114 \\
\hline \multicolumn{8}{|l|}{ Uruguay } \\
\hline 1872 & 0.65 & 0.48 & 0.74 & 3.92 & 0.1 & 2,181 & 556 \\
\hline 1920 & 0.61 & 0.56 & 0.92 & 12.82 & 0.1 & 2,674 & 209 \\
\hline \multicolumn{8}{|l|}{ Averages } \\
\hline 1872 & 0.64 & & & & & & \\
\hline 1920 & 0.63 & & & & & & \\
\hline Total & 0.64 & & & & & & \\
\hline \multicolumn{8}{|c|}{ Panel C: Own estimates at current prices of subsistence and mean income } \\
\hline \multicolumn{8}{|l|}{ Brazil } \\
\hline 1872 & 0.83 & 0.56 & 0.68 & 4.71 & 0.1 & 198 & 64 \\
\hline 1920 & 0.73 & 0.60 & 0.81 & 16.65 & 0.1 & 2,649 & 489 \\
\hline \multicolumn{8}{|l|}{ Chile } \\
\hline 1870 & 0.89 & 0.59 & 0.67 & 16.27 & 0.1 & 145 & 48 \\
\hline 1920 & 0.88 & 0.64 & 0.73 & 24.29 & 0.1 & 2,033 & 550 \\
\hline
\end{tabular}

$\mathrm{IPF}=$ Inequality Possibility Frontier. 